\title{
Türkiye'de Yeniden Evlenme Olgusu: Cinsiyet ve Psikososyal Değişkenler Bağlamında Bir Değerlendirme
}

\author{
DOI: $10.26466 /$ opus. 935681
}

\author{
Alpaslan Çobanoğlu* Serhat Tek $^{* *}$ \\ * Öğr. Gör., Bitlis Eren Üniversitesi, Sağlık Yüksekokulu, Sosyal Hizmet Bölümü, Bitlis/Türkiye \\ E-Posta: acobanoglu@beu.edu.tr \\ ORCID: $\quad 0000-0003-1536-4854$ \\ ** Doç. Dr., Bitlis Eren Üniversitesi, Sağlık Yüksekokulu, Sosyal Hizmet Bölümü, Bitlis/Türkiye \\ E-Posta: stek@beu.edu.tr \\ ORCID: $\quad \underline{0000-0001-7140-2099}$
}

Öz

Aile kurumu toplumsal değişmelerin hızlanması ile birlikte dönüşmeye başlamıştır. Bireylerin ve toplumların olguya yükledikleri anlamda yıllar içerisinde bir takım farklılaşmalar olduğu görülmektedir. Alana ilişkin yapılan çalışmalarda bu durumun özellikle boşanma ve yeniden evlenme eğilimlerinde artışa sebep olduğu belirtilmektedir. Yeniden evlenme sıklıkla eş kaybr ve evlilik akitlerinin sonlandırılması sonucunda ortaya çıkan bir durumdur. Yeniden evlenme süreci psikolojik, sosyal, ekonomik, kişilerarası, ailevi, çevresel ve toplumsal bir takım problemleri beraberinde getirebilmektedir. Son yıllarda Sosyoloji, psikoloji ve sosyal hizmet gibi disiplinlerde yeniden evlenme konusu sıklıkla kuramsal ve olgusal düzeyde ele alınmaktadır. Türkiye'de yeniden evlenme olgularınn cinsiyet, yalnız olma nedeni ve psikososyal değiş̧kenler bă̆lamında değerlendirilmesi amacıla yapılan bu araştırmada betimsel analiz yönteminden yararlanılarak konu ile ilgili daha önce hazırlanmış olan çalışmalar ve yayınlanmış istatistikler analiz edilerek incelenmiştir. Çalışmada kullanılan nicel veriler Türkiye İstatistik Kurumu tarafindan yayınlanan 'Karşılaştırmalı Medeni Duruma Göre Evlenmeler' ve 'Boşanma' istatistiklerinden derlenerek ele alınmıştır. Çalışma kapsamında incelenen veriler ışı̆̆ııda, eşlerden birinin ölümü sebebiyle evliliği sonlanmış bireyler arasından yeniden evlenenlerin sayısının boşanmış bireylere göre daha düşük olduğu görülmüş̧ür. Kadınlarda 2001-2019 yıllar arasında yeniden evlenme artış oranının \%84 olarak gerçekleştiği, bu oranın erkeklerde ise \%72 olduğu belirtilmiştir. Eşlerden birinin ölümü veya boşanma sebebiyle bekar olan erkek ve kadınlarm yeniden evlenme hizları yıllara göre artmaktadır. Kadınlarda ve erkeklerde yeniden evlenme hizinın 2001-2019 yılları arasında \%44 arttı̆̆ı görülmüştür. Çalışmadan elde edilen veriler ışığında aile kurumunun dönüşümüyle birlikte yeniden evlenme ilişkin eğilimlerin de değiştiği tespit edilmiştir. Yeniden evlenme olgusunun bireyler üzerinde olumlu velveya olumsuz psikososyal etkileri olduğu ve cinsiyete bağhl olarak değişkenlik gösterdiği ortaya konulmuştur.

Anahtar Kelimeler: Yeniden Evlenme, Boşanma, Eş Kaybı, Yeniden Evlenme İle Oluşan Aileler. 


\title{
Remarriage Phenomenon in Turkey: An Evaluation in the Context of Gender and Psychosocial Variables
}

$*$

\begin{abstract}
The concept of family has begun to transform with the acceleration of social changes. The meaning that individuals and societies attach to the concept of family has changed over the years. This situation led to an increase in divorce and remarriage tendencies according to field researches. Remarriage processes often occur as a result of the loss of a spouse and the termination of marriage contracts. As a matter of fact, the remarriage process may bring along some psychological, social, economic, interpersonal, familial, environmental and social problems. Disciplines such as sociology, psychology and social work carry out theoretical and factual studies on remarriage. This review was conducted to assess the psychosocial context of remarriage phenomenon in Turkey. In this research, it was conducted to evaluate remarriage cases in Turkey in the context of gender, reason of being single and psychosocial variables, also previous studies and published statistics on the subject were descriptively analyzed and examined. The quantitative data used in the study published by the Turkey Statistical Institute 'Comparative marriage by marital status' and 'divorce' has been compiled from statistics. In the light of the data examined within the scope of the study, it was observed that among individuals whose marriage was terminated due to the death of one of the spouses, the number of remarried individuals was lower than those who were divorced. It has been stated that the rate of remarriage increase in women between $2001-2019$ was $84 \%$ and this rate was $72 \%$ for men. The rate of remarriage increases over the years for men and women who are single due to the death of one of their spouses or divorce. It was observed that the rate of remarriage for men and women increased by $44 \%$ between 2001-2019. In the light of the data obtained from the study, it has been determined that the tendencies towards remarriage have changed with the transformation of the family institution. It has been revealed that the phenomenon of remarriage has positive and/or negative psychosocial effects on individuals and varies depending on gender.
\end{abstract}

Key Words: Remarriage, Divorce, Spouse Loss, Remarriaged Families. 


\section{Giriş}

Sosyal bilimlerin geçmişten bu yana önemli inceleme alanlarından biri olan aile olgusu sosyal değişmenin hız kazandığı günümüz toplumlarında da yoğun şekilde ilgi çeken bir konu haline gelmiştir. Bilindiği üzere aile, farklı disiplinlerin kendi kuram ve yaklaşımları bağlamında konu edindiği toplumsal bir kurumdur. Aile kurumu tarihsel süreçte yapısal olarak büyük değişikliklere uğramış olsa bile birey ve toplum arasında adeta bir köprü vazifesi görmeye devam etmektedir. Bu sebeple aile kurumu içinde gerçekleşen karşılıklı etkileşimler bireylerin hem psikolojik hem de sosyal gelişimlerine etki eden başat faktörler arasında gösterilmektedir. Aile sistemini oluşturan bireylerin psikolojik, ekonomik, kültürel ve sosyal birtakım özellikleri sistemik yapının kendisini etkilemekle birlikte temas içinde olduğu üst ve alt sistemlerle olan ilişkisi bakımından da önem arz etmektedir. Aile yaşam döngüsünün başlangıcını ve bitişini belirleyen süreçler evlenmenin gerçekleşmesi ve sona ermesidir. Evlenme, toplumsal, kültürel, dini ve ekonomik değeri olan önemli bir süreçtir. Geçmişten günümüze kişi ve toplumlar evlilik akdiyle kurulan aile kurumuna önemli değerler atfederken aynı zamanda aileye önemli sorumluluklar da yüklemiştir. Aile toplumun temel taşı olarak ifade edilmekle birlikte, eşlerin ve çocukların birlikte olduğu, toplumsal değerlerle yoğrulmuş bir şekilde yaşayan, yeni nesillerin de benzer değerler ile yetişmelerini sağlamakla yükümlü olarak görülmektedir. Uzun yıllar bu düşüncenin hâkim olduğu aile yapısı, toplumsal değişmelerin hızlanması ile birlikte dönüşmeye başlamış, aileyi oluşturan bireyler ve bu bireylerin çevreleyen sosyal ağların aileye verdikleri anlam ve aile kurumundan beklentileri değişime uğramıştır.

Küreselleşmenin etkisi ile birlikte; farklı toplumlarla iletişimin kolaylaşması, yaşanılan ülke dışındaki toplumlarda değişen yeni aile yapılarının ve yaşamlarının daha net bir şekilde izlenebiliyor olması, aileye verilen anlamın ve aile kurumundan beklentilerin dönüşmesine sebep olmuştur. Bu anlamda aile kurmak kolaylaşırken, aynı zamanda aile ilişkisini sonlandırmak da önceki dönemlere kıyasla daha kolay hale gelmiştir. 
Boşanma kavramı toplumsal açıdan düşünüldügünde, toplum içerisinde aileye atfedilen anlama bağlı olarak kavramın farklı şekillerde algılandığ1 ifade edilmektedir. Bu anlamda her toplumun boşanan bireylere olan bakış açısı değişkenlik gösterebilmektedir. İçinde yaşanılan toplumun boşanmaya atfettiği anlam, bireylerin yaşadığı ya da yaşayacağı psikolojik zorluğun boyutunu da değiştirebilmektedir. Ayrıca boşanmış çiftlerin aile kavramına bakışları, aileden beklentileri farklı olabilmekte, bu farklılık boşanan bireylerin boşanmadan sonraki hayatlarını etkileyebilmektedir.

Evliliğinde mutlu olmayı bekleyip de herhangi bir sebeple bu beklentisi yerine gelemeyen ve yine kendi isteği olmasa bile evliliği sonlanan bireylerin evliliğe bakış açıları bir takım farklılıklar içermektedir. Ayrıca yaşadığı sorunlardan dolayı boşanmayı bir kurtuluş olarak gören bireylerin evliliğe bakış açıları da birbirinden farklı olabilmektedir. Ayrıca boşanma bazı durumlarda yeniden evlenme sürecinin başlatılmasında önemli bir ön koşul olarak görülmektedir

Evlenmeler ve boşanmalar süreç olarak farklılıklar gösterebilmektedir. Önceleri ömür boyu süren evlilikler yaygınken günümüzde evliliğe yüklenen anlamın değişmesiyle birlikte görece daha kısa süreli evliliklerin söz konusu olabildiğini söylemek zor olmayacaktır. Evlenen bireylerin demografik özellikleri ve evlilik sürecinde yaşananlar ilişkilerin gidişatını etkileyebilmektedir. Her ne sebeple olursa olsun, evliliğin sonlanmasının eşler üzerinde birtakım psikolojik sonuçlara sebep olduğu bilinmektedir. Evlilik akdinin sonlanması ile birlikte yaşanan süreçte geçici veya kalıcı sürelerle taraflarda psikolojik güçlüklerin ortaya çıktığı ifade edilmektedir.

Evli kalınan süreye olan özlem, tek başına yaşamama isteği, ekonomik, psikolojik ve toplumsal olarak başkası ile birlikte yaşama gereksinimi gibi sebeplerle bireyler yeniden evlenme isteği içerisinde olabilmektedir. Eşlerden birinin kaybı ile sonuçlanan sürece binaen gerçekleştirilen yeniden evlenmeler de söz konusu olabilmektedir. Evli kalınan ve ailenin dağılmasından sonraki dönemde yaşanan psikolojik sorunlar, yeniden evlenme ile giderilmeye çalışılabilmektedir. Esasında bu yeni durum da kendi içerisinde yeni birtakım psikolojik sorunları ortaya çıkarabilmektedir. Önceki evliliğe göre daha iyi olabileceği düşünülen yeniden evlenmeler, bir araya gelen çiftlerin geçmiş 
yaşanmışlıklarından getirdikleri ile birlikte daha olumlu ve istenen ya da daha olumsuz ve istenmeyen durumların ortaya çıkmasına sebep olabilmektedir.

Yapılan çalışmada ilk olarak boşanma olgusu yeniden evlenme süreçlerine etki eden bir faktör olarak değerlendirildiğinden istatistiki verilerin süreç içerisindeki değişimi ele alınmıştır. Araştırma yeniden evlenme olgusunu cinsiyet, yalnız olma nedeni ve psikososyal değişkenlerle beraber değerlendirmeyi amaçlayan betimsel bir araştırmadır. Betimsel araştırmalar hâlihazırdaki koşul ve durumları bütüncül bir bakış açısıyla açıklamayı hedefleyen çalışmalardır. Araştırmanın evreni Türkiye'de 2001 ve 2019 yılları arasında yeniden evlenen kadın ve erkeklerden oluşmaktadır. Araştırma kapsamında ele alınan evren geniş bir popülasyonu içerdiğinden dolayı çalışma küme örnekleme modelinden yararlanılarak tasarlanmıştır. Küme örneklem modelinde örneklemin farklı özelliklerinden oluşan veriler tabakalara ayrılarak ele alınmaktadır (Krysik ve Finn, 2015).

$\mathrm{Bu}$ araştırmanın sorunsalı Türkiye'de yeniden evlenme olgusuna dair yapılmış olan çalışmaların konu alanları incelendikten sonra şekillendirilmiştir. Yeniden evlenmeyi belirli değişkenleri dikkate alarak ele alan çalışmaların görece az olduğu saptanmıştır. Bu noktada araştırmanın problemi Türkiye'de yeniden evlenme eğilimlerinin cinsiyete ve yalnız olma nedenine göre yıllar içerisinde değişkenlik gösterip göstermediğinin ortaya konulmasıdır.

Araştırma kapsamında Türkiye İstatistik Kurumu (2020) tarafından yayınlanan boşanmaya dair veriler, yeniden evlenmeye ilişkin veriler ve evlilik ve boşanma hızını karşılaştırmalı olarak ele alan veriler bir arada sunulmuştur. Araştırma 2001-2019 yılları arasındaki verilerden elde edilen betimsel analizlerle sınırlıdır. Bu veriler ışığında alana dair mevcut çıktılar analiz edilerek çalışmada yeniden evlenme olgusunun bireyler üzerinde olumlu ve/veya olumsuz etkileri olup olmadığı, varsa bunun psikososyal etkilerinin neler olduğu ve bu etkilerin cinsiyet ve yalnız olma nedeni değişkenlerine bağlı olarak farklılık gösterip göstermediğinin irdelenmesi amaçlanmıştır. 


\section{Yeniden Evlenme İle Oluşan Aileler}

Toplumları meydana getiren özellikler birbirinden farklılaşabilmektedir. Bu farklılaşan özelliklere bakıldığında, her toplumun aile yapısının belli açlardan benzersiz olduğunu ifade etmek zor olmayacaktır. Zaman içerisinde farklı ülkelerin ve toplumların aile yapılarında değişimlerin yaşandığı, benzer şekilde aynı ülkenin kırsal kesimi ile şehirlerindeki aile yapılarının da birbirinden farklı hale gelmeye başladığı belirtilmektedir (Bayer, 2013). Tarihsel süreç içerisinde fonksiyonel ve yapısal değişime uğrayan aile kurumunun bazı özelikleri sürekliliğini korurken, bazı özellikleri unutularak yerine yeni özellikler gelmiştir. Özellikle geleneksel toplumdan modern topluma geçiş ile birlikte evlilik de başkalaşmıştır. Bu anlamda aile içerisinde yaşanan ilişkiler, aile bireylerinin üstlendikleri roller farklılaşmaya başlamış, evlenme ve ailenin anlamı ile aile içi rol ve statüler yeniden şekillenmiştir (Tekin Epik, Çiçek ve Altay, 2017).

Eski dönemlerde evlilikten beklenenlerle bugün beklenenler birbirinden oldukça farklıdır. Önceleri evlilik; dini, toplumsal bir gereklilik gibi algılanırken modern toplumlarda bu durum daha fazla hak elde etme, çlkar sağlama düşüncesine değin yeni süreçlere evrilmiştir (Bekmuradov, 2007). Bu evrilmenin evliliklerin ömür boyu devam edeceği düşüncesinin de değişmesine ve evliliklerin daha kısa sürmesine sebep olduğu ifade edilebilir.

Evliliğe ilişkin bakış açılarındaki ve evliliğe yüklenen anlamlardaki değişiklikler sonucunda Köşer Akçapar ve Egbatan (2020)'a göre boşanmalardaki artışla birlikte yeniden evlenmelerde de önemli oranda bir artış söz konusudur. Bu durum toplumdan topluma, kültürden kültüre yeni bir takım anlamlar içeren yeniden evlenme konusunu sosyal bilimciler açısından çalışılması gereken bir olgu olarak konumlandırmıştır.

Yeniden evlenmenin kavramsal açıdan tanımlamasına bakıldığında Cherlin (2010), kavramın karmaşık yapısından ve bu anlamda değişen tanımlamaların olabileceğinden söz etmektedir. Demirci (2015), yapmış olduğu tanımlamada süreci boşanma sonrası resmi bir bağ kurma yolu ile tarafların bir araya gelmesi olarak ifade etmektedir. Dainton (2019), tanımlamasında yeniden evlenmeye ilişkin kavramsal terminolojinin 
öneminden söz ederken Price-Bonham ve Balswick (1980), ise iki kişi arasındaki yasal ve sosyal bir anlaşmadan bahsetmektedir. Shriner (2009), çiftlerden en az birinin daha önce evlilik yapmış olmasının gerekliliğine vurgu yapmaktadır.

Günümüzde evlenme olgusuna atfedilen anlamın değişmesiyle birlikte boşanmalarda da artış söz konusu olmaya başlamıştır. Boşanma kavramına bakış ve bireyleri boşanma tutumuna iten sebepler değişmekle birlikte; genel anlamda boşanmanın toplumsal, kültürel ve bireysel farklılıklardan kaynaklandığı ifade edilmektedir. Boşanmanın yaygınlaşması ve boşanma oranlarındaki artışın toplumsal değişimle bağlantılı olarak ifade edilen özel anlamda farklılaşan sebepleri de bulunmaktadır. Bu sebepler arasında sosyal, kültürel, dinsel, ekonomik ve psikolojik nedenler sayılabilir (Tatlılığlu ve Demirel, 2016).

Aile sistemi içerisinde yer alan tüm bireyler boşanma sürecinden etkilenmektedir. Ancak boşanmanın bazı aile üyelerini görece daha fazla etkilediğini ifade eden çalışmalar bulunmaktadır. Kaplan, Abay, Bükecik, Şahin, Arıöz Düzgün ve Bay Karabulut (2018)'a göre boşanma sürecinde kadınların toplumsal statüleri, sosyoekonomik koşulları ve aile içi sorumlulukları sebebiyle daha savunmasız grupta yer aldıkları belirtilmektedir. Boşandıktan sonra kadına toplum tarafından yüklenen bir etiket olan 'dul kadın' olma hali, kadınların daha zor boşanma kararı almalarına sebep olabilmektedir. Yavuz ve Yüceşahin (2012)'e göre ise boşanma ya da eş kaybı sonucu yalnız ebeveyn olarak yaşamlarına devam etmek zorunda kalan kadınların sosyal normlar ve anneliğe atfedilen anlam sebebiyle yeniden evlenme konusunda erkeklere göre daha fazla zorlandığ 1 ifade edilmektedir.

\section{Yeniden Evlenme Olgusuna Kuramsal Yaklaşım}

Aile alanında yapılan çalışmalar sosyal bilimlerin farklı disiplinleri tarafından yürütülmektedir. Postmodern süreçte değişen aile tanımlamaları bağlamında yeni bir takım çalışma konuları gündeme gelmiştir. Bu bağlamda aile kavramının irdelendiği konuya göre temel alınan kuramsal yaklaşımlar da farklılaşmaktadır. Bu çalışma özelinde aile ile ilgili kuramlar sosyoloji, psikoloji ve sosyal hizmet bilimleri bağlamında ele alınmaya çalışılmıştır. 
Yeniden evlenmeye bağlı olarak kurulan aileler daha önce de ifade edildiği gibi sıklıkla boşanma sonrası veya eşlerden birinin kaybı sonucunda gerçekleşmektedir. Bu açıdan boşanma olgusunun kuramsal tahlilini yapmak yerinde olacaktır. Boşanmanın, kadın ve erkek arasındaki psikolojik, sosyal ve ekonomik gerilimler neticesinde gerçekleştirildiği varsayılırsa feminist kuramın bu olguyu açıklamada ideal bir noktada konumlandığı ifade edilebilir. Yaklaşık olarak ikiyüz yılı aşkın bir süredir ele alınan feminist kuram hem liberal hem de marksist alanda kendini konumlandırmada çelişkiler yaşamaya başlayınca, 1970 sonrası dönemde daha özgün bir kuram olma eğilimi hissederek bağımsızlık kazanmıştır (Tuğ, 2016). Bilhassa Birleşik Krallık'ta 19.yüzyılın ilk dönemlerinde feminist hareketler 'aile rüyası' algısının kadını öteki olarak konumlandırdığ 1 fikrinde birleşmişlerdir (Berktay, 2012). Nicel veriler ışığında son yıllarda Türkiye'de gerçekleşen boşanma eğilimindeki artış, eşler arasındaki cinsiyetçi unsurların yarattığı çatışmalar üzerinden okunmaktadır. Dolayısıyla yeniden evlenme süreçlerine sebep teşkil eden boşanma olgusu bu çalı̧̧mada daha çok feminist kuram perspektifinden ele alınmıştır.

Boşanma aile içi ilişkiler bağlamında ele alındığında gerek birey gerekse de aile sistemleri açısından psikolojik yönleriyle birlikte incelenmesi gereken bir olgu olarak değerlendirilmektedir. Boşanma konusuna genel perspektiften bakıldığında sürecin aile yaşam döngüsünü sonlandırdığı iddia edilmektedir. Ancak Nichols (2013) aile yaşam döngüsü içinde boşanmanın artık anormal bir durum olarak sinıflandırılmaması gerektiğini belirtmektedir. Bu bilgiden hareketle boşanma olgusunun da aile yaşam döngüsünün bir bileşeni olarak ele alınabileceği düşünülmektedir. Yeniden evliliğin aile yaşam döngüsünün yeni bir evresi olarak değerlendirilebileceği, önceki yaşam deneyimlerinin psikolojik etkilerinin yeni evliliklere de yansıyabileceği düşünülmektedir. Böylece eşlerin psikolojik ve sosyal durumlarını ele alırken yeniden evliliklerde önceki evlilik deneyimlerinin etkili bir faktör olduğu değerlendirilmektedir.

Aile üzerine yapılan çalışmalarda aileyi bir bütün olarak analiz etmek ve ailenin genel çerçevesini belirlemek açısından Ludvig Van Bertalanffy tarafından geliştirilen genel sistem yaklaşımından yararlanılmaktadır (Akün, 2017). Bu yaklaşımın temel savı, genel sistemlerin alt 
sistemlerden oluştuğu ve bu alt sistemlerin hem birbirine hem de genel sistemin kendisine etkide bulunduğudur. Diğer bir ifadeyle alt sistemlerden birinde meydana gelen değişiklik, diğer alt sistemleri değiştirdiği gibi genel sistemi de değiştirici özelliğe sahiptir. Sonuç olarak bu döngüsellik, değişimi ilk olarak başlatan alt sistemin kendisine de etki etmektedir. Bunun yanında diğer alt sistemler ve genel sisteme de nüfuz ederek durumdan etkilenmelerine yol açabilmektedir (Nichols ve Schwartz, 1997). Bu bağlamda aile bireylerinin her biri bütünsel bir sistemin alt sistemleri olarak değerlendirilebilir. Yeniden evlenmeler sonucunda oluşan ailelerde eşler arasında ya da aralarında kan bağı bulunmayan çocuk ve ebeveynler arasındaki problemler diğer alt sistemlere ve sistemin bütününe etki edebilme potansiyeline sahiptir. Dolayısıyla yeni aile üyelerinin etkileşiminden doğan problemler biyolojik aile üyeleri arasındaki ilişkileri de etkilemektedir. Bu yaklaşım aile ilişkilerini açığa çıkarmada ana çerçeveyi ortaya koymak açısından önemli görülmektedir.

Virginia Satir öncülüğünde geliştirilen yaşantısal aile terapisi kuramı, aileyi şimdi ve burada bakış açısıyla ele alarak birey ve bireylerarası deneyimlere odaklanmaktadır. Yaşantısal terapinin temelinde konumlanan varsayım; ailenin duygulanım, güdüler ve yaşantılar bağlamında özgür bırakılmasının önemine dikkat çekmektedir. Bu durum ailenin gelişimine etki eden bir unsur olarak nitelendirilmektedir. Ayrıca bireylerin tek başlarına deneyimleri de ailenin bütünsel deneyimlerine katkılar sunabilmektedir (Nichols, 2013). Yaşantısal aile terapisi, yeniden evlenmeler ile oluşan ailelerin deneyimleri üzerine de çalışmalar yürütmektedir. Sistem kuramından temellenen bu terapötik yaklaşım, katı psikoterapi yöntemlerinin bireylerin ve ailelerin değişen ve gelişen ihtiyaçlarını karşılamada yetersiz kaldığını ifade ederek süreçte öne çıkan ihtiyaçları şu şekilde sıralamıştır:

- Kişinin ailedeki rolü kapsamında kurduğu iletişimi gözlemleme ihtiyac1

- Bireylerin davranışsal ve bireysel farkındalıklarının aile sistemi içerisinde nasıl konumlandı̆̆

- Terapi esnasında ailede gözlemlenen yeni davranış örüntülerinin aileyle paylaşılması (Yıldırım, 2017). 
Yeniden evlenme ile oluşan aileleri, birey- aile- çevre bağlamında ele almak açısından işlevsel olan bir diğer yaklaşım Bronfenbrenner (1979) tarafından geliştirilen ekolojik kuramdır. Bu yaklaşıma göre birey kendisini aşamalı olarak çevreleyen aşamalı sistemlerin merkezinde olan bir organizma olarak ele alınmaktadır. Bu beş aşama; mikro, mezzo, egzo, makro ve krono sistemlerden meydana gelmektedir. Ekolojik yaklaşımda bireye en yakın konumda olan bireyleri ele alan mikro sistem; aile üyelerini ve yakın arkadaşları içerisine alan mezzo sistem, mezzo sistemler ile kurumsal mekanizmalar arasındaki ilişkiyi açıklamada egzo sistem; topluluk ve toplumsal süreçlerle etkileşimleri ele alan makro sistem; ve bütün katmanları içine alan ve etkileşimin sınırlı olduğu krono sistem bulunmaktadır. Ekolojik yaklaşımda aşamalı bir küme modelinden söz edilmektedir. Bu kümenin içindeki tüm sistemlerin canlı ve değişken olduğu kabul edilmektedir (Bilge, Avcı, Dinçel, Alkış Demirel, Karatekin, Koç ve Demirtaş Zorbaz, 2015). Ekolojik kuram, sistem yaklaşımından temellenen bir yaklaşım olsa da her iki yaklaşımın da kendilerine ait terminolojileri vardır (Gitterman ve Germain, 2008). Ekolojik kuramın temel savı kişinin çevresiyle denge kurmayı başarması durumunda sosyal çevresi ile ilgili gelecekte yaşanması muhtemel problemlerin önlemesine dayanmaktadır (Danış, 2006). Bu yaklaşım bireyin kendi kültürel değerleri, inançları, kabulleri ile toplumsal beklentiler arasında bir köprünün kurulabileceğini ifade etmektedir (Teater, 2013). Yeniden evlenme ile oluşan aileler, ekolojik yaklaşım açısından değerlendirildiğinde; bireye ilişkin durumları açıklamada mikro, aile ilişkilerini açıklamada mezzo ve toplumsal ilişkileri açıklamada ise makro uygulama boyutlarından yararlanılmaktadır.

Yukarıda paylaşılan bilgilerden hareketle, yeniden evlenme ile oluşan aileler üzerine yapılan çalışmalarda sosyal bilimlerin paydaş disiplinleri temelinde farklı pek çok kuramdan yararlanılabilmektedir. Bu farklı bakış açıları konunun spesifik yönlerini ele almanın yanında bütüncül bir yapıyı da inşa etmektedir. 


\section{Yeniden Evlenmelere İlişkin Gerçekleştirilen Akademik Çalışmalar}

Yeniden evlenme literatürü incelendiğinde olgunun toplumda görülme sıklığındaki değişimlere paralel olarak son yıllarda yeniden evlenmeleri odağına alan çalışmaların artış eğiliminde olduğu gözlemlenmektedir.

Literatüre ilişkin öncü çalışmaların sıklıkla 1980'li yıllarda yayınlandığı görülmektedir. Spanier (1984), boşanma sonrası gerçekleşen yeniden evlenmeler üzerine çalışmalar gerçekleştirmiştir. Dahl, Cowgill, ve Asmundsson (1987) tarafından yapılmış olan çalışmada yeniden evlenme sürecine ilişkin genel bir çerçeve çizilmiştir. Çalışmada evliliğin ilk yılları, aidiyet hissi, çiftlerin ve çocukların durumu, belirlenen normlar, yeniden evlenen çiftlerin tavsiyeleri konularına değinilmiştir. Crosbie-Burnett (1989) ise yeniden evlenme sürecine ilişkin yapılandırdığı çalışmasında dönemin stres yaratan yapısına dikkat çekerek 'yeniden evlenme sürecinde aile stres teorisi' konusunu ele almıştır. Çalışmada dönemin zorlukları, yeniden evlenme sürecine ilişkin algı, kriz dönemi, biyolojik olmayan çocukların yeni aile içindeki pozisyonları ve politikalar konularına değinilmiştir.

2000'li yıllarla birlikte, akademik çevrelerin konuya olan ilgisinin artmasına binaen farklı alanlara eğilen çalı̧̧maların sayısı da artış göstermiştir. Hetherington (2003) yeniden evlenme sürecinde çocuklara yönelik sosyal destekler; Greeff ve Du Toit (2009) yeniden evlenme sürecinde psikolojik sağlamlık; Sherman ve Bauer (2008) yeniden evlenme sürecinde yaşanan finansal çatışmalar; Papernow (2015) ise yeniden evlenme sürecinde ebeveynlik konusu üzerinden yeniden evlenme olgusunu ele almıştır.

Yapılan literatür taramalarında Türkiye'de ise son yıllarda yeniden evlenme konusunda yapılmış çalışmaların arttığı görülmektedir. Öztan (2004)'ın yeniden evlenmeyi hukuki süreçler bağlamında incelediği; Arpacı ve Tokyürek (2012)'in boşanmış bireylerin yeniden evlenmeleri konusundaki görüşlerinin incelenmesini amaçladığı; Demirci (2015)'nin kadın ve erkeklerin gözünden boşanma ve yeniden evlenme konusunu araştırdığı; Dirimeşe (2016) ve Zeybekoğlu Dündar (2016)'ın konuyu tanımsal boyutta ele aldığı; Özabacı ve Erkan (2017)'ın ise yeniden evlenmeyi aile terapileri bağlamında incelediği görülmektedir. 


\section{Yeniden Evlenmelere İlişkin Yayınlanan İstatistiki Bilgiler}

Bu bölümde Türkiye'de yeniden evlenme olguları ile ilgili TÜİK(2020) tarafından yayınlanmış istatistikler incelenmiştir. Çalışmada kullanılan nicel veriler Türkiye İstatistik Kurumu "Karşılaştırmalı Medeni Duruma Göre Evlenmeler" ve "Boşanma" istatistiklerinden yararlanılarak alana ilişkin betimsel tablolar oluşturulmuştur. Çalışma kapsamında ele alınan veriler 2001-2019 yılları arasındaki boşanma veya eşlerden birinin kaybı sonrası gerçekleştirilen yeniden evlenmelere ilişkin istatistiki bilgilerdir. İncelenen bilgiler 1şı̆̆ında, 2001-2019 yılları arasındaki evlenme, boşanma, yeniden evlenme öncesinde kadın ve erkeğin durumu ile yeniden evlenme durumları yıllara göre sıralanarak yorumlanmıştır.

2001-2019 yıları arasında eşlerden birinin ölümü veya boşanma sebebiyle ayrılan eşlerin yeniden evlenme durumları ile ilgili istatistiki veriler aşağıdaki tablolarda yer almaktadır.

Tablo 1. 2001-2019 Yilları Arasında Boşanma İstatistikleri (TüİK, 2020)

\begin{tabular}{lll}
\hline Yll & Evlenme & Boşanma \\
\hline 2001 & 544.322 & 91.944 \\
2002 & 510.155 & 95.323 \\
2003 & 565.468 & 92637 \\
2004 & 615.357 & 91.022 \\
2005 & 641.241 & 95.895 \\
2006 & 636.121 & 93.489 \\
2007 & 538.311 & 94.219 \\
2008 & 641.973 & 99.663 \\
2009 & 501.742 & 114.162 \\
2010 & 582.715 & 118.568 \\
2011 & 592.775 & 120.117 \\
2012 & 603.751 & 123.325 \\
2013 & 600.138 & 125.305 \\
2014 & 599.704 & 130.913 \\
2015 & 602.982 & 131.830 \\
2016 & 594.793 & 126.164 \\
2017 & 569.459 & 128.411 \\
2018 & 554.389 & 143.573 \\
2019 & 541.424 & 155.047 \\
\hline
\end{tabular}

Tabloya göre 2001-2019 yıları arasında evlenme sayılarında azalma olmuştur. 2009 yılında belirgin bir düşüş olmuş, 2010 yılında evlenenlerin sayısı yükselse de 2008 yılındaki 641.973 sayısına ulaşamamıştır. 
Tabloya bakıldığında Türkiye'de 2001-2019 yılları arasında boşanma hızının yaklaşık olarak \%69 oranında arttığı görülmektedir. Boşanma hızlarındaki artış yıllara göre doğrusal bir şekilde yükseliş gösterirken 2002, 2005, 2009, 2018 ve 2019 yıllarında hizlı artışların olduğu 2003, 2004, 2006, 2016 yillarında ise bir önceki yıla göre düşüş olduğu görülmektedir.

Tablo 2. 2001-2019 Yıllar Arasında Yeniden Evlenenlerin Yalniz Olma Nedeni (TüİK, 2020)

\begin{tabular}{lllcc}
\hline Yıl & \multicolumn{1}{c}{ Kadın } & \multicolumn{2}{c}{ Erkek } \\
\hline 2001 & Eş Kaybı & Boşanma & Eş Kaybi & Boşanma \\
2002 & 8.927 & 37.066 & 14.500 & 42.150 \\
2003 & 8.833 & 28.565 & 13.460 & 43.019 \\
2004 & 9.680 & 33.092 & 13,644 & 47,769 \\
2005 & 9.370 & 35.115 & 13,645 & 50,520 \\
2006 & 9.297 & 36.785 & 13.058 & 52.562 \\
2007 & 10.549 & 39.768 & 12.414 & 56.649 \\
2008 & 3.882 & 47.713 & 11.893 & 57.078 \\
2009 & 3.893 & 50.689 & 12.088 & 60.796 \\
2010 & 3.596 & 52.418 & 11.281 & 62.469 \\
2011 & 3.729 & 54.782 & 11.330 & 63.840 \\
2012 & 3.667 & 59.502 & 10.875 & 68.870 \\
2013 & 3.593 & 64.618 & 10.902 & 74.168 \\
2014 & 3.578 & 64.277 & 10.250 & 72.801 \\
2015 & 3.438 & 66.135 & 9.874 & 73.811 \\
2016 & 3.405 & 68.507 & 9.680 & 75.406 \\
2017 & 3.484 & 70.690 & 9.863 & 77.373 \\
2018 & 3.385 & 67.685 & 9.273 & 72.900 \\
2019 & 3.317 & 67.909 & 9.329 & 72.893 \\
\hline
\end{tabular}

Tablo 2'de yeniden evlenen bireylerin evlenmeden önceki medeni durumları yer almaktadır. Tabloya göre yeniden evlenenlerin çoğunluğunun daha önceki evliliğini boşanma sebebiyle bitirmiş olan kişiler olduğu görülmektedir. Eşlerden birinin ölümü sebebiyle evliliği sonlanmış bireyler arasında yeniden evlenenlerin sayısının daha az olmasını, yaşlanmaya bağlı eş kayıplarının oluşturduğu düşünülmektedir. Yaşlanma kaynaklı kayıplarda eşlerin ikisinin de yaşlarının ilerlemiş olması ve eşlerden birinin kaybı sonrasında diğer eşin yeniden evlenmeyi pek fazla düşünmediği söylenebilir.

Eşi vefat etmiş kadınlarda ve erkeklerde yeniden evlenme hızının yıllar itibariyle düştüğü görülmektedir. Kadınlarda daha hızlı olan bu düşüş, erkeklerin yaklaşık üçte biri kadardır. Bu oran erkeklerde de \%65 
düşüş olarak gerçekleşmiştir. Eşini kaybetmiş erkeklerin yeniden evlenmeleri yıllar itibariyle düzenli bir seyirle düsserken, bu durum kadınlarda 2006 yılı sonrasında çok hızlı olarak gerçekleşmiş, eşi ölmüş kadınlarda yeniden evlenme yaklaşık olarak \%172 düşmüştür. Erkeklerde ise boşandıktan sonra yeniden evlenme sayılarının düzenli bir şekilde arttığı, 2016 yılından sonra belirgin bir düşüş olduğu ve 2017, 2018, 2019 yıllarında yaklaşık olarak aynı seviyede devam ettiği görülmektedir.

Boşanma yoluyla eşinden ayrılan bireylerde ise yeniden evlenme hızının yıllara göre artış gösterdiği görülmektedir. Boşanmış kadınlarda yeniden evlenme sayılarında 2007 yılında hızlı bir artış olurken 2002, 2013 ve 2017 yıllarında bir önceki yıla göre düşüş görülmektedir. 20122013 yılları ile 2017-2018 yıllarında yeniden evlenme sayıları birbirine çok yakın düzeydedir.

Kadınlarda 2001-2019 yılları arasında yeniden evlenme artış oranı \%84 olarak gerçekleşirken erkeklerde bu oran \%72 olmuştur. Buna göre kadınların erkeklere göre daha yüksek oranda yeniden evlenmeye yöneldikleri görülmektedir.

Tablo 3. 2001-2019 Yılları Arasında Cinsiyete Göre Yeniden Evlenme (TüIK, 2020)

\begin{tabular}{llll}
\hline Yll & Kadın & Erkek & Toplam \\
\hline 2001 & 45.993 & 56.650 & 113.300 \\
2002 & 37.398 & 56.479 & 112.958 \\
2003 & 42.772 & 61.413 & 122.826 \\
2004 & 44.485 & 64.165 & 128.330 \\
2005 & 46.082 & 65.620 & 131.240 \\
2006 & 50.317 & 69.063 & 138.126 \\
2007 & 51.595 & 68.971 & 137.942 \\
2008 & 54.582 & 72.884 & 145.768 \\
2009 & 56.014 & 73.750 & 147.500 \\
2010 & 58.511 & 75.170 & 150.340 \\
2011 & 63.169 & 79.745 & 159.490 \\
2012 & 68.211 & 85.070 & 170.140 \\
2013 & 67.855 & 83.051 & 166.102 \\
2014 & 69.573 & 83.685 & 167.370 \\
2015 & 71.912 & 85.086 & 170.172 \\
2016 & 74.174 & 87.236 & 174.472 \\
2017 & 71.070 & 82.173 & 164.346 \\
2018 & 71.226 & 82.222 & 164.444 \\
2019 & 71.428 & 81.451 & 162.902 \\
\hline
\end{tabular}


Tablo 3'e bakıldığında eşlerden birinin ölümü veya boşanma sebebiyle bekar olan kadınların evlenme hızı yıllara göre artış göstermekle birlikte bu artış 2002, 2013, 2017 yıllarında düşmüş, 2017, 2018, 2019 yıllarında ise yaklaşık olarak aynı seviyede gerçekleşmiştir. Eşinin ölümü ya da boşanma sebebiyle bekar olan erkeklerden yeniden evlenenlerde de yıllar içerisinde bir artış eğilimi söz konusu iken, 2002, 2007, 2013, 2017 yıllarında düşüş, 2013, 2008, 2011, 2012 yıllarında belirgin yükselişler olmuştur. Eşlerden birinin ölümü veya boşanma sebebiyle bekar olan bireylerin yeniden evlenme hızlarının yaklaşık \%44 arttı̆̆1 görülmektedir. Sayısal olarak bakıldığında da eşlerden birinin ölümü veya boşanma sebebiyle bekar olan erkeklerin kadınlara göre daha fazla yeniden evlendiği anlaşılmaktadır.

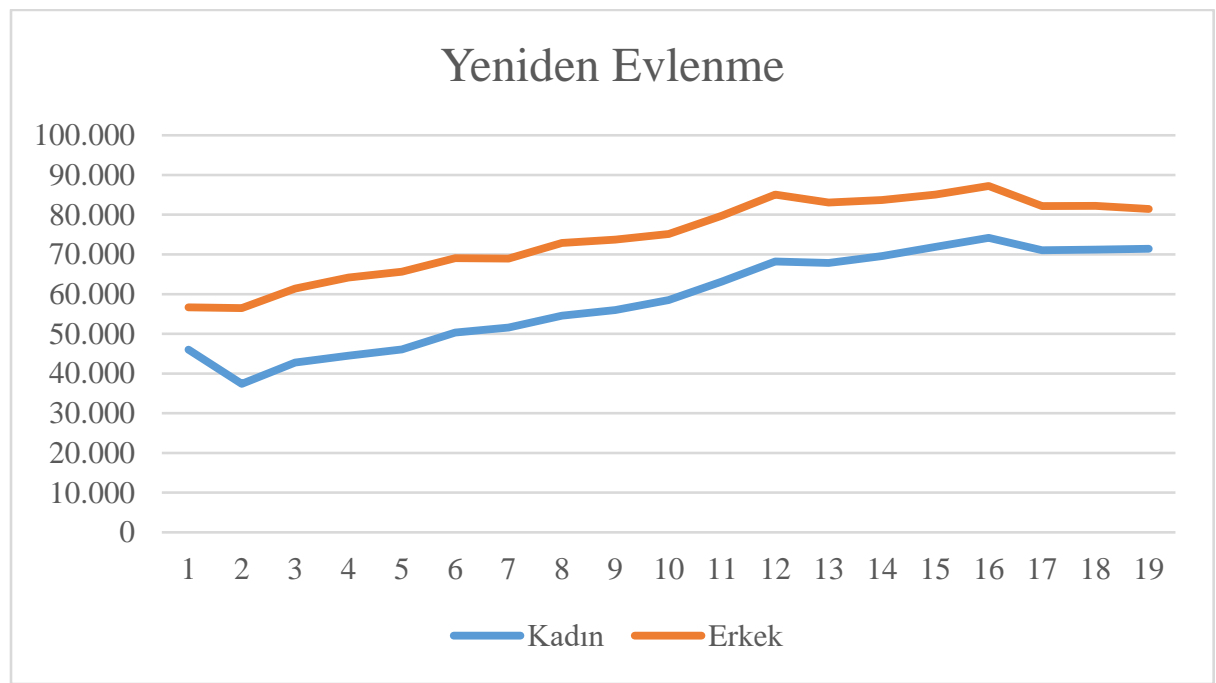

Şekil 1. 2001-2019 Yılları Arasında Cinsiyete Göre Yeniden Evlenme

Şekil 1'de eşlerden birinin ölümü veya boşanma sebebiyle bekar olan erkek ve kadınların yeniden evlenme seyri görülmektedir. Kadınların ve erkeklerin yeniden evlenme hızlarında iki grupta da belirgin bir yükseliş görülürken farklı oranlarda olmakla birlikte evlilik hızındaki düşme ve yükselmelerin benzer yıllara denk geldiği anlaşılmaktadır. 


\section{Yeniden Evlenme ile Oluşan Ailelerde Psikolojik ve Sosyal Durum}

Evlenmenin herhangi bir sebepten ötürü sonlanması ya da eşlerden birinin kaybı nedeniyle bireyler bekar statüsüne geri dönmektedir. Bazı bireyler bekar olarak yaşantılarını devam ettirirken bazı bireyler ise yeniden romantik ilişkiler kurup bu ilişkiyi de evlenme yoluyla resmileştirme motivasyonu içerisinde olabilmektedir. Gerek boşanma sonrası gerekse de eş kaybı sonrası bireyler yas süreci yaşayabilmektedir. Ayrıca yeniden evlenme olgularında çocukların durumu da önem arz etmektedir. Bu bağlamda yeniden evlenme, yeni yaşamın kurgulanması sürecinde farklı psikolojik deneyimlerin ortaya çıkmasına etki etmektedir.

Walsh (2001) yeniden evlenme olgularına ilişkin yapmış olduğu çalışmada ailelerin psikolojik ve sosyal süreçleriyle ilgili üzerinde durulması gereken 20 önemli konudan söz etmiştir:

- Çocuklu ailelerdeki yeni ebeveynlerin nasıl isimlendirileceği

- Yeni ebeveyn ile etkileşim- ayrılınan ebeveyn ile etkileşim

- Biyolojik ebeveynin kaybi

- Yeni aile üyeleri arasındaki sevgi iletişimi

- Ayrılık sürecinin çocuklar üzerinde yarattığı hayal kırıklığı

- Yeni ebeveynin disiplin anlayışı

- Aile rollerindeki karmaşa

- Kardeşler arası çatışmalar

- Ayrılınan ebeveyn ile yeni ebeveyn arasında paylaşılan zaman konusundaki rekabet

- Metaaile (büyüyen aile) bağlantısı oluşturmak

- Yeni kurulan ailede çiftlerarası cinsel uyum

- Zaman içindeki değişim

- Çocukların yeni aileden uzaklaşması ve yeni aileye katılımı

- Toplumun yeniden evliliğe bakışı

- Bireysel kendilik algisı

- Ailenin kendilik algis1

- Ebeveynliğin yeni aile ilişkisine etkisi

- Yeni evlenmelerle birlikte gelen finansal yükümlülükler

- Devam eden ebeveyn çatışmaları

- Velayet konusunda ebeveynler arası çatışmalar 
Yapılan çalışmalarda boşanma ve eş kayıpları sonrası bireylerde birtakım psikopatolojilerin gözlenebildiği belirtilmektedir. $\mathrm{Bu}$ psikopatolojilerin bir kısmı şu şekildedir:

- Hayattan eskisi kadar zevk alamamak,

- İsteksizlik,

- İçinden bir şey gelmemek,

- Uyku bozukluğu,

- İştahsızlık ya da bazen aşırı iştah artışı,

- Yorgunluk,

- Uyunmasina rağmen dinlenememe,

- Unutkanlık,

- Dikkat azalması,

- Gerginlik (Aktaş, 2018).

$\mathrm{Bu}$ psikopatolojilerin yanında boşanmış bireylerin ekonomik, çevresel, aile baskısı, duygusal sorunlar gibi genel bir takım problemleri deneyimledikleri belirtilmektedir. Ayrıca özellikle kadınlara yönelik tacize maruz bırakılma gibi birçok sosyal sorunun da yaşandığı ifade edilmektedir (Arpacı ve Tokyürek, 2012).

Sosyal ve psikolojik sorunların baskısı içerisinde olan boşanmış bireylerin yeniden evlenmeye karşı bakış açıları değişebilmektedir. Yaşanılan sorunların etkisiyle bazen bu durum bireylerde geri çekilmeye ve yeni bir romantik ilişkiden kaçınmaya sebebiyet verirken bazen ise sürecin verdiği zararları atlatabilmek ve yeni bir hayat kurmak gibi sebeplerle bireyi yeniden evlenmeye yönlendirebilmektedir. Yeniden evlenme kararında etkili olan faktörler arasında;

- Çiftlerin eğitim ve refah düzeyleri,

- Kadınların ev dışında çalışmaları,

- İlk evlenme yaşı,

- Boşanma yaşı,

- Çocukların varlığı gibi faktörler etkin rol oynamaktadır.

Yeniden evlilik kararlarının yukarıda belirtilen faktörlere ve bireysel ihtiyaçlara göre farklılaşabildiği belirtilmelidir. Yeniden evliliklerde cinsiyetler arası farklılıklar ve çocukların varlığı gibi faktörler ebeveynlerin yeniden evlilik kararlarını etkilediği belirtilmektedir (Yüksel Kaptanoğlu, Eryurt ve Koç, 2000). Bu noktada yeniden evlenmeye ilişkin karar verme sürecinde bireylerin farklı duygu 
durumlar içerisinde olabildiği ve süreçten psikososyal bağlamda etkilendikleri görülmektedir.

\section{Tartışma ve Sonuç}

Aile kurumu toplumsal açıdan her dönem değerini korumuş bir sistemdir. Ancak günümüzde aile kurumuna atfedilen değer başkalaşarak herkes için farklılaşan anlamlara evrilmiştir. Bu noktada toplumsal yaşamda gerçekleşen değişimler, aile sistemini de etkilemiş, evlenmeler ve boşanmalar daha kolay karar verilir bir hal almaya başlamıştır. $\mathrm{Bu}$ durum yeniden evlenmeleri gündeme getirmiştir. Yeniden evlenme olgularının artmasıyla birlikte sosyal bilimlerde bu alana yönelik çalışmalar artış göstermiştir. Kuramsal düzeyde özellikle sosyoloji, psikoloji ve sosyal hizmet gibi disiplinler alana yönelik çalışmalar yapmaktadır. Sosyolojik araştırmalar makro düzeyde konumlanırken, psikoloji ve sosyal hizmet araştırmaları mezzo ve mikro düzeyde uygulama ve müdahaleler gerçekleştirmektedir.

Yeniden evlenme süreçleri kişilerarası ilişkiler ve bireylerin toplumla entegrasyonu gibi konularda zorlu bir takım yaşam olaylarını içerebilmektedir. Bu noktada bireysel, ailevi, çevresel, kültürel, sosyal, ekonomik, psikolojik vb. bir takım sorun alanları görünür hale gelmiştir.

Dünyanın pek çok ülkesinde olduğu gibi Türkiye'de de yeniden evlenme olguları son yıllarda artış göstermiştir. Bu bağlamda konuya ilişkin kamusal veriler yayınlanmaya başlanmıştır. $\mathrm{Bu}$ çalışma kapsamında TÜİK tarafından yeniden evlenme, boşanma ve eş kaybına ilişkin yayınlamış olan istatistiki veriler incelenerek, Türkiye örnekleminde konu görünür kılınmaya çalışılmıştır.

Boşanmış kadınların ve erkeklerin farklı düzeylerde yaşadıkları ekonomik, sosyal ve psikolojik sorunlar, onlarda yeniden evlenme düşüncesinin oluşmasına yol açabilmekte, eşlerden birinin ölümü veya boşanma sebebiyle yalnız kalan erkek ve kadınlar yeniden evlenmeyi tercih edebilmektedir. Çalışma kapsamında eşlerden birinin ölümü veya boşanma sebebiyle bekar olan erkek ve kadınların bir kısmının yeniden evlendikleri belirlenmiştir. Eşlerden birinin ölümü sebebiyle evliliği sonlanmış bireyler arasından yeniden evlenenlerin sayısı boşanmış bireylere göre daha düşüktür. Kadınlarda 2001-2019 yılları arasında 
yeniden evlenme artış oranı \%84 olarak gerçekleşirken bu oranın erkeklerde \%72 olduğu belirlenmiştir. Bu durum yeniden evlenme kararı almada toplumsal cinsiyet eşitsizliğine bağlı bir takım gelişmelerin Türkiye özelinde bir yansıması olarak yorumlanmaktadır. Daha açıklayıcı bir ifade ile son yıllarda Türkiye'de kadınların ekonomik, eğitsel ve kültürel düzeyde güçlenmesinin yeniden evlenme kararının alınması noktasında etkili olduğu düşünülmektedir.

Yeniden evlenme düşüncesinin altında farklı sebepler yatabilmektedir. Eşlerden birinin ölümü veya boşanma sebebiyle bekar olan erkek ve kadınların mevcut durumlarını değiştirmek ve yeni bir aile kurma düşüncesi ile yeniden evlenme kararı verebildikleri görülmektedir. Çalışma kapsamında incelenen verilerden hareketle, eşlerden birinin ölümü veya boşanma sebebiyle bekar olan erkek ve kadınların yeniden evlenme hızları yıllara göre artış göstermektedir. Kadınlarda ve erkeklerde yeniden evlenme hızının 2001-2019 yılları arasında \%44 arttı̆̆ 1 belirlenmiştir. Bu durum Türkiye'de yeniden evlenme olgusuna ilişkin toplumsal baskıların hem kadın hem de erkekler açısından azaldığını göstermekle birlikte, evlenme eğilimlerinde bireysel kararların daha etkin bir unsur olmaya başladığını da ortaya koymaktadir.

İncelenen veriler ışı̆̆ında Türkiye'de boşanma ve yeniden evlenme oranlarındaki artıştan hareketle aile kurumunun yapısal değişikliklere uğradığı görülmektedir. Toplumsal değişmenin dinamik unsurlarının aile kurma deneyimlerini çeşitlendirdiği ve yeniden evlenme kararlarında artışa sebep olduğu söylenebilir. Bu durum günümüzde yeniden evlenme tercihlerini toplumda nadir görülen olaylar olmaktan çıkarıp olgusal bir sosyal gerçekliğe dönüştürmüştür. Bu olgusal gerçeklik çoğu zaman psikolojik ve sosyal bir takım sorunlara sebebiyet verebilmektedir. Dolayısıyla alana ilişkin gerçekleştirilen çalışmalar bu bütüncül bakış açısıyla değerlendirilmelidir. Bireyin, ailenin ve toplumun refahını yüceltme amacıyla oluşturulan sosyal politikaların toplumda giderek artan yeniden evlenme olgusunu da kapsayacak biçimde güncellenmesi gerekliliği doğmaktadır. Bu bağlamda yeniden evlenme olgusunu deneyimleyen birey ve ailelere yönelik psikolojik, sosyal ve ekonomik destek hizmetlerinin kapsamının ve kalitesinin arttırılması yerinde olacaktır. Özellikle yeniden evlenme ile ortaya çıkan 
ailelerde ebeveynler arasında ya da biyolojik olmayan ebeveynle çocuklar arasında ortaya çıkması muhtemel sorunların bütüncül bir bakış açısıyla ele alınması gerekmektedir. Bu bütünsellik unsuru kapsamında yeniden evlenme ile ortaya çıkan yeni aile biçiminin toplumsal ve bireysel refah açısından önemine dikkat çekerek bu yönde politikalar geliştirmenin sosyal devlet anlayışının temsil gücünü arttıracağ 1 düşünülmektedir. 


\title{
EXTENDED ABSTRACT
}

\section{Remarriage Phenomenon in Turkey: An Evaluation in the Context of Gender and Psychosocial Variables}

\author{
Alpaslan Çobanoğlu - Serhat Tek \\ Bitlis Eren University
}

Even though the family institution has undergone major structural changes in the historical process, it continues to serve as a bridge between the individual and the society. For this reason, the mutual interactions that take place within the family institution are shown among the dominant factors that affect both the psychological and social development of individuals. While some psychological, economic, cultural and social characteristics of the individuals who make up the family system affect the systemic structure itself, it is also important in terms of its relationship with the upper and lower systems it is in contact with. The processes that determine the beginning and end of the family life cycle are the realization and termination of marriage. Marriage is an important process with social, cultural, religious and economic value. Individuals and societies have attributed important values to the family institution established by the marriage contract, while at the same time, they have also assigned important responsibilities to the family from the past to the present. Although the family is expressed as the cornerstone of society, it is seen as responsible for ensuring that the new generations, who live together with spouses and children and live in a way that is kneaded with social values, are brought up with similar values. The family structure, which has been dominated by this idea for many years, has begun to transform with the acceleration of social changes, the individuals who make up the family and the meaning given to the family by the social networks surrounding these individuals and their expectations from the family institution have changed.

In the study, the phenomenon of divorce was evaluated as a factor affecting the remarriage processes. For this purpose, the change of statistical data in the process is discussed. The research is a descriptive study aiming to evaluate the phenomenon of remarriage together with 
gender, reason for being alone and psychosocial variables. Descriptive studies are studies that aim to explain current conditions and situations with a holistic perspective. The concept of the research consists of men and women who remarried between 2001 and 2019 in Turkey. Since the concept covered in the research includes a large population, the study was designed using the cluster sampling model. In the cluster sampling model, the data consisting of different characteristics of the sample are handled by stratification.

The problem of this research has been shaped after examining the subject areas of the studies on the phenomenon of remarriage in Turkey. It has been determined that there are relatively few studies dealing with remarriage by considering certain variables. At this point, the gain of the research is to reveal whether the tendency to remarry in Turkey varies over the years according to gender and the reason for being alone. Within the scope of the research, the data published by the Turkish Statistical Institute were used. These data are data on divorce, data on remarriage, and data on marriage and divorce rates. The research is limited to the descriptive analyzes obtained from the data between 20012019. In the light of these data, the current outputs of the field were analyzed. In the study, the positive and/or negative effects of remarriage on individuals and their psychosocial effects were examined. In addition, it is aimed to examine whether these effects differ depending on the variables of gender and reason for being alone.

The family institution is a system that has preserved its social value in every period. However, today the value attributed to the family institution has evolved into different meanings for everyone. At this point, the changes in social life also affected the family system, and marriages and divorces began to become easier to decide. This situation has brought remarriage to the agenda. With the increase in remarriage cases, studies on this field in social sciences have increased. At the theoretical level, disciplines such as sociology, psychology and social work are working on the field. While sociological research is located at the macro level, psychology and social work research carries out practices and interventions at the mezzo and micro level. 
Remarriage processes can involve a number of difficult life events such as interpersonal relations and integration of individuals with society. At this point, individual, familial, environmental, cultural, social, economic, psychological etc. a number of problem areas have become visible.

As in many countries of the world, remarriage cases have increased in Turkey in recent years. In this context, public data on the subject has begun to be published. Within the scope of this study, the statistical data published by TÜIK on remarriage, divorce and loss of spouse were examined and the subject was tried to be made visible in the Turkish sample.

The economic, social and psychological problems experienced by divorced women and men at different levels can lead to the formation of the idea of remarriage in them. Men and women who are left alone due to the death of a spouse or divorce may choose to remarry. Within the scope of the study, it was determined that some of the men and women who were single due to the death of one of their spouses or divorce remarried. Among individuals whose marriage has ended due to the death of one of their spouses, the number of remarried individuals is lower than that of divorced individuals. While the rate of increase in remarriage was $84 \%$ in women between 2001-2019, it was determined that this rate was $72 \%$ in men. This situation is interpreted as a reflection of some developments related to gender inequality in the decision to remarry in Turkey. In other words, it is thought that women's economic, educational and cultural empowerment in Turkey in recent years has been effective in making the decision to remarry.

There may be different reasons behind the thought of remarriage. It is seen that men and women who are single due to the death of one of their spouses or divorce may decide to remarry with the thought of changing their current situation and establishing a new family. Based on the data analyzed within the scope of the study, the rate of remarriage of single men and women who are single due to the death of one of their spouses or divorce increases over the years. It was determined that the rate of remarriage in women and men increased by 44\% between 2001-2019. This situation shows that the social pressures regarding the remarriage phenomenon have decreased in terms of both women and men in 
Turkey, and it also reveals that individual decisions have started to become a more effective factor in marriage tendencies.

In the light of the analyzed data, it is seen that the family institution has undergone structural changes due to the increase in divorce and remarriage rates in Turkey. It can be said that the dynamic elements of social change diversity the experiences of starting a family and cause an increase in remarriage decisions. This situation has turned remarriage preferences from being rare events in society into a factual social reality. This factual reality can often cause some psychological and social problems. Therefore, the studies carried out in the field should be evaluated from this holistic perspective. It is necessary to update the social policies created to promote the welfare of the individual, the family and the society in a way that includes the increasing remarriage phenomenon in the society. In this context, it would be appropriate to increase the scope and quality of psychological, social and economic support services for individuals and families who experience remarriage. Problems that may arise between parents or between non-biological parents and children, especially in families resulting from remarriage, need to be addressed with a holistic perspective. It is thought that developing policies in this direction by drawing attention to the importance of the new family form that emerged with remarriage within the scope of this integrity element in terms of social and individual welfare will increase the representation power of the social state understanding.

\section{Kaynakça / References}

Aktaş, Ç. (2018). Boşanmanın erkekler üzerindeki etkisi: İstanbul örneği. İmgelem, 2(2), 29-57.

Akün, E. (2017). Yapısal Aile Sistemleri Kuramı bağlamında ergenlik döneminde aile yapısı ve ergenlik dönemi sorunları. Ankara Üniversitesi Dil ve Tarih-Coğrafya Fakültesi Dergisi, 53(1), 85-116.

Arpacl, F. Tokyürek, Ş. (2012). Boşanmış bireylerin yeniden evlilik konusundaki görüşlerinin incelenmesi. Akademik Bakış Dergisi, 31, 115. 
Bayer, A. (2013). Değişen toplumsal yapıda aile. Şırnak Üniversitesi İlahiyat Fakültesi Dergisi, 4(8), 101-129.

Bekmuradov, M. (2007), Özbek ailelerinde tutum özellikleri, günümüzde aile, (Ed. Ö. Çaha). Uluslararası Aile Sempozyumu. İstanbul: Ensar Neşriyat.

Berktay, F. (2012) Tarihin cinsiyeti. İstanbul: Metis Yayınları.

Bilge, F., Avcı D., Dinçel, E. F., Alkış Demirel, E., Karatekin, H., Koç, Ö. ve Demirtaş Zorbaz, S. (2015). The use of systems approach in pscyhological counseling and guidance. (Ed: Ş.Ş. Erçetin \& S. Banerjee). Chaos, Complexitiy and Lidership 2013. Switzerland: Springer International Publishing.

Cherlin, A. (2009). Marriage, divorce, remarriage. MA: Harvard University Press.

Crosbie-Burnett, M. (1989). Application of family stress theory to remarriage: A model for assessing and helping stepfamilies. Family Relations, 38(3), 323-331.

Dahl, A. S., Cowgill, K. M., ve Asmundsson, R. (1987). Life in remarriage families. Social Work, 32(1), 40-44.

Dainton, M. (2019). Equity and relationship maintenance in first marriages and remarriages. Journal of Divorce E Remarriage, 60(8), 583-599.

Danış, M. Z. (2006). Davranış bilimlerinde ekolojik sistem yaklaşımı. Aile ve Toplum Dergisi, 8(3), 45-53.

Demirci, M. S. (2015). Toplumsal cinsiyet açısından yeniden evlenmeler: kadın ve erkekler gözünden niteliksel bir inceleme. Yüksek Lisans Tezi. Hacettepe Üniversitesi, Sosyal Bilimler Enstitüsü, Ankara.

Dirimeşe, E. (2016). Aile tanım ve türleri tarihsel süreç içerisinde aile (Tarihsel Aile Sinıflaması). N. Avcı ve E. Aksoy (Ed.). Aile Sosyolojisi içinde. (s.13-28). İstanbul: Lisans Yayınları.

Greeff, A. P. ve Du Toit, C. (2009). Resilience in remarried families. The American Journal of Family Therapy, 37(2), 114-126.

Hetherington, E. M. (2003). Social support and the adjustment of children in divorced and remarried families. Childhood, 10(2), 217-236.

Kaplan, S. Abay, H. Bükecik, E. Şahin, S. Arıöz Düzgün, A. Bay Karabulut, A. (2018). Türkiye'de yapılan çalışmalar bağlamında kadınlarda boşanmanın nedenleri (2000-2018): Sistematik derleme. Uluslararası Bilimsel Araştırmalar Dergisi, 3(2), 821-833.

Köşer Akçapar ve Egbatan (2020). Aile, boşanma ve yeniden evlilikler olgusuna sosyolojik bir bakış: sorunlar ve tavsiyeler. Koç Üniversitesi Toplumsal Cinsiyet ve Kadın Çalışmaları Araştırma ve Uygulama 
Merkezi (KOÇ-KAM) Yayını. Erişim: https://kockam.ku.edu.tr/ailebosanma-yeniden-evlilikler-olgusuna-sosyolojik-bir-bakis-sorunlartavsiyeler/ Erişim Tarihi: 20.02.2021

Krysik, J. L. ve Finn, J. (2015). Etkili uygulama için sosyal hizmet araştırması. Çev. Ed. E. Erbay. Ankara: Nika Yayınevi.

Nichols, M. P. (2013). Aile terapisi: Kavramlar ve yöntemler. İstanbul: Kaknüs Yayınları.

Nichols, Michael P. and Richard C. Schwartz. (1997). Family therapy: Concepts and methods. Usa: Allyn and Bacon.

Özabacı, N. ve Z. Erkan. (2017). Aile danışmanlı̆̆ı kuram ve uygulamalara genel bir bakış. (3. Bask1). Ankara: Pegem Akademi.

Öztan, B. (2004). Aile hukuku. Ankara: Turhan Kitapevi.

Papernow, P. L. (2015). Becoming a stepfamily: Patterns of development in remarried families. Mahvah NJ: CRC Press.

Price-Bonham, S. ve Balswick, J. O. (1980). The noninstitutions: Divorce, desertion, and remarriage. Journal of Marriage and the Family, 42(4), 959-972.

Sherman, C. W. ve Bauer, J. W. (2008). Financial Conflicts facing late-life remarried alzheimer's disease caregivers. Family Relations, 57(4), 492503.

Shriner, M. (2009). Marital quality in remarriage: A review of methods and results. Journal of Divorce $\mathcal{E}$ Remarriage, 50(2), 81-99.

Spanier, G. B. (1984). Recycling the family: Remarriage after divorce. Beverly Hills, Calif.: Sage Publications.

Tatlılıoğlu, K. ve Demirel, N. (2016). Sosyal bir gerçeklik olarak boşanma olgusu: sosyal psikolojik bir değerlendirme. Akademik Sosyal Araştırmalar Dergisi, 4(22), 59-73.

Teater, B. (2014). An introduction to applying social work theories and methods. McGraw-Hill Education (UK).

Tekin Epik, M., Çiçek, Ö. ve Altay, S. (2017). Bir sosyal politika aracı olarak tarihsel süreçte ailenin değişen/değişmeyen rolleri. Sosyal Politika Çalışmaları Dergisi, 17(38), 35-58.

Tuğ, B. (2016). Tarih ve toplumsal cinsiyet. F. Saygıligil (Ed.) Toplumsal Cinsiyet Tartışmaları. İçinde, s.33-50. İstanbul: Dipnot Yayınları.

TÜİK, Türkiye İstatistik Kurumu. https://data.tuik.gov.tr/Search/Search?text=bo\%C5\%9 FanmaEdil=1 (15.11.2020) 
Walsh, W. M. (1992). Twenty major issues in remarriage families. Journal of Counseling \& Development, 70(6), 709-715.

Yavuz, S. ve Yüceşahin, M. M. (2012). Türkiye'de hanehalkı kompozisyonlarında değişimler ve bölgesel farklılaşmalar. Sosyoloji Araştırmaları Dergisi, 15(1), 75-118.

Yüksel Kaptanoğlu, İ. Eryurt, M. A. ve Koç, İ. (2000). Kadınların evlilik döngüsü: evliliğin sonlanması ve yeniden evlenme. Kadın/Women, 13(1), 63-96.

\section{Kaynakça Bilgisi / Citation Information}

Çobanoğlu, A. ve Tek, S. (2021). Türkiye'de yeniden evlenme olgusu: cinsiyet ve psikososyal değişkenler bağlamında bir değerlendirme. OPUS- Uluslararası Toplum Araştırmaları Dergisi, 18(44), 8092-8118. DOI: 10.26466/opus.935681. 